\title{
Tax competition for FDI in Central-European Countries ${ }^{1}$
}

\begin{tabular}{|l|l|}
\hline Milan Sedmihradsky & Stanislav Klazar \\
\hline Department of Public Finance & Department of Public Finance \\
University of Economics Prague & University of Economics Prague \\
Faculty of Finance and Accounting & Faculty of Finance and Accounting \\
13067 Prague 3, W. Churchill sq.4 & 13067 Prague 3, W. Churchill sq. 4 \\
Czech Republic & Czech Republic \\
\hline sedmih@volny.cz & klazar@vse.cz \\
\hline
\end{tabular}

JEL classification: F21, H25, K34

\section{Introduction}

The inflow of foreign direct investments is a crucial factor of economic growth. In the last decade all transition countries have adopted investment incentives to attract foreign investors and speed up their rate of economic growth. A typical incentive package contains exemption or significant reduction of income tax up to 10 years, grants for retraining of labour force or other subsidies.

Looking back we can conclude that such a policy proved to be useful and really increased the inflow of FDI to candidate countries. However we can argue, whether such measures are consistent with the EU competition policy and how significant the redirection of FDI is. The European Union published already in 1996 the Code of conduct for business taxation, which aims at repeal of all inconsistencies in tax systems of Member States. Also OECD declared in 1998 and 2000 its will to cope with all forms of harmful tax competition.

The paper is structured as follows: First we give a brief description of development of tax incentives in Hungary, Poland, Slovakia and Czech Republic. After that we analyze more closely the case of Czech Republic and its legislation of investment incentives. This legislation was designed to meet all requirements of OECD and European Commission and has a high degree of transparency, accountability and flexibility. Nevertheless the Commission forces all candidate countries including Czech Republic to repeal all investment incentives during pre-accession negotiations.

We conclude our analysis with presentation of empirical research on the influence of investment incentives on FDI inflow. We found out quite interesting results - adoption of investment incentives in Poland and Czech Republic had a significant impact on redirection of FDI flow from Hungary to those countries. Moreover the total inflow increased three times in the last three years. We can argue that in fact the investment incentives attracted more FDI from outside of the region. The fundamental questions are which impact the investment incentives and public support in the area of direct taxation have on economic activity? How such measures as tax holidays are effective and should European Commission prevent them?

We look at this sensitive issue from the perspective of less developed candidate countries and we hope that it will be a good starting point for discussion about a broader European integration and the role of more developed and less developed countries. The tools we are describing can promote the economic growth; on the other hand how can be their harmful effect minimised?

\subsection{Tax Competition Theories and Harmful Tax Competition}

Tax competition is one of the issues, which has been brought by the economic globalisation. This phenomenon described already Tiebout (1956) on taxation of a mobile production factor, which can move freely between jurisdictions (countries, governments, municipalities). The level of welfare depends on tax revenue from a tax imposed on that factor and provided public goods. Each jurisdiction sets the tax rate and provides the amount of public goods to maximise the inflow of mobile factor from other jurisdictions.

As a result of that, the tax rate in each jurisdiction and amount of provided public goods will be suboptimal e.g. the tax rate and tax revenues will be too low to finance the required level of public goods, whereas the distribution of the mobile factor will be the same as in the case of a higher single tax rate. Modern literature stresses on the other hand the positive effect of tax competition for reduction of inefficient public

\footnotetext{
${ }^{1}$ The research has been undertaken with the support of the Jean Monnet doctoral grant CZ 99/001.
} 
expenditures, see for instance Boss (1999) or Black, Hoyt (1989). An overview of theories of tax competition is given in Wilson (1999).

In our paper we would like to focus on tax competition in form of investment incentives by which the countries of Central and Eastern Europe attract foreign investments. Mostly they use reduction of corporation income tax and other fiscal advantages. The question is, whether such a behaviour does not meet characteristics of harmful tax competition as defined in OECD (1998) and EC (1997) and whether the result is not only reduction of tax revenues without significant increase of investments.

\subsection{Harmful tax competition}

In the past decade both the European Union and OECD became aware of the tax competition endangering the fiscal balance of developed countries. OECD (1998) uses the term harmful tax competition to describe tax heavens and preferential tax regimes designed primarily for tax avoidance of non-residents, without real economic activities.

The report defines the harmful tax competition by following characteristics:

- the effective tax rate is zero or much lower then ordinary

- there is no effective exchange of information between the tax heaven and tax authorities of other countries

- the regime is not transparent and does not require any economic activity from the non-resident

From the above given criteria we can conclude, that mere reduction of tax burden is not considered to be a harmful tax competition. A significant feature is lack of co-operation and no obligation to carry out a real business operation in the tax heaven. Similar characteristics are mentioned also in EC (1997).

\subsection{Taxes as an incentive instrument}

The power of taxation should not be overestimated. As for instance Tanzi, Zee (2000) indicate, much more important are other factors such as availability of natural resources, economic and political stability, transparent legal environment, efficient public administration, infrastructure and cost-efficient and skilled labour force. Nevertheless they admit that if two countries do not differ too much in other factors, unilateral tax measures can be effective. We suppose this is the case of Central Europe. Since the preferential regime is considered to be a strong and potentially abuseable tool, the taxpayers are often concentrated into special zones, which are more strictly controlled.

Easson (1998) distinguishes following types of zones:

1. Customs and trade zones - are not considerd to be part of the country's customs area and neither imports nor exports are subject to customs and excise duties or VAT.

2. Manufacturing and production zones - in addition to the same advantages as customs zones, they grant also exemption from income tax and other taxes related to invested money. Both types of zones are designed for manufacturing of goods for export.

3. Special economic zones - have a separate tax regime, but basically do not grant exemption from import and excise duties. Unlike the zones of the first two types, they are not physically separated from environment, since the advantages granted do not concern movement of goods. In this category belongs also an exemption of particular investor from income tax.

In comparison to exemption of total income, investment incentives and tax credits are much more transparent. They can target the particular investment projects and allow quantification of their costs for the government budget. The assigned tax authority records the tax credit on the investor's tax account. The credit is reduced by the annual tax liability but only up to the initially granted amount.

Therefore the size of the incentive can be limited without regard to the time, when the limit is reached. In case of a global 5-year exemption, the investor can in a bad situation save nothing, if he does not achieve profit within that time. As a result of that, the global exemption often deteriorates large-scale investments and on the other hand it supports small fast returning investments more then desired. That is why we think tax credit is a better tool.

\section{Investment incentives in CEE countries}

In the description of each country the reader should pay attention to the fact, that we are talking only about recent investment incentives, still effective and designed to attract large-scale foreign investments. We do not go far into details of repealed investment incentive schemes and tax incentives for SME and start-ups or mere replacement of machinery. However even in case of repealed incentives, the taxpayers, who got them, are able to use the advantages till the end of agreed period, which means that they are still effective for them. 


\subsection{Poland}

Thanks to a large Polish diaspora, there was already in the communist time an interest from foreign investors in investments in Poland. First legislation was adopted already in 1976 and in 1983 the Decree on joint ventures provided companies with foreign participation two-year tax holidays. In 1988 the tax holidays were prolonged for companies with at least $20 \%$ foreign participation up to three or six years.

In 1991 this law was amended and a tax credit for the tax liability equal to initial invested amount was introduced for investments at least 2000000 ECU. The decision about who will receive the credit was in competence of the Minister of Finance, and criteria such as the rate of unemployment in the region, new technologies, and percentage of exported production should be taken into account. The system was not very transparent.

After the 1993 tax reform there were no special tax incentives for foreign investors, they could benefit from reduction of the tax liability only in the year, when the investment occurred. The reduction was between 20 and $75 \%$ depending on the invested amount and unemployment in the region.

Special economic zones were established between 1995 and 1997. In total there are 19 zones which should attract investments to regions with high unemployment and low developed regions in the North and South of Poland and Silesia. Some of them are almost at the Czech borders such as zones Kamienna Góra and Walbrzych in the former mining area near Trutnov or Jelenia Góra near Jablonec. Most of the zones are established for 20 years and during that time they provide tax advantages to taxpayers, who carry out their business exclusively in the zone. The advantages are specific for each zone, generally the consist of:

1. Exemption of income from taxation up to the amount of invested amount. Should the investment exceed a given threshold, the income is fully exempted. The threshold is between 350000 EUR in Suwalki and 2000000 EUR in zone Kraków.

2. $10 \%$ reduction of income tax for each 10 employees up to $100 \%$ in particular zones, the reduction is 20 or $25 \%$ for each 10 employees. Not applicable in zones Kraków and Mazowiecka.

3. Exemption of $50 \%$ of income from exported goods produced and services provided in the zone Mielec. The advantages are granted to the investor for 10 years (in the zones Kraków and Mazowiecka only for 6 years) and basically can be used any time during the existence of the zone. After the 10-year exemption ellapses, only $50 \%$ of income is exempted. Moreover next to a reduction or an exemption of the taxable income, buildings are exempted from the real estate tax.

Since 1998 no more zones were established, due to opposition of the European Union, which strictly requires that all the state aid has to be in line with the association agreement. From 2000, no more incentives in the special economic zones are granted ${ }^{2}$.

\subsection{Hungary}

In Hungary the preferential regime for foreign investors was introduced alredy in 1980s, which offered a much lower tax rate then for domestic companies. Since 1988 foreign companies have become the subject to the ordinary corporation tax system, however with an entitlement to special advantages. For instance companies with at least $30 \%$ foreign participation, which invested more then 50000000 HUF (about 500000 USD) could reduce their tax liability by $60 \%$ in the first 5 years of their operations and by $40 \%$ in additional 5 years.

This system was repealed in 1993, however already in the next year the government introduced a 10year exemption from taxation for investments exceeding 500 mil. HUF, if the profit was reinvested in Hungary. Since 1.1. 1995 a new corporation tax was introduced. The tax rate was reduced from 36 to $18 \%$ with an additional rate $23 \%$ on distributed profits. In 1996 the additional tax on distributed profit was transformed into a $20 \%$ the withholding tax on dividends, which is by most double-tax conventions reduced to $5 \%$. Moreover if the investment exceeds one billion HUF (approx. 5 millions USD), the tax rate is reduced to a half, in certain cases to zero for 5 years. Since 1998 the investors, who invest at least 10 billions HUF in stipulated low developed areas, are eligible for a 10-year tax holidays, if the investor creates 500 new jobs and the turnover annually grows at least by $5 \%$. Those incentives are available till 2011 . Next to the tax holidays, the investor can use incentives for small scale investments and retraining of labour force.

According to Easson (1998), there is a competition between regions, which want to attract investors by infrastructure or subsidised price of real estates. Besides above described incentives the Hungarian government established like Poland a few special economic zones in regions with high unemployment, which grant 5-year tax holidays. They are attractive especially by low threshold of the investment to qualify for the advantages.

Hungary is the only country in the region, which has a special law on offshore companies. Due to this form of harmful tax competition it appeared also on the OECD list. The company, which meets following conditions can tax its profit by a $3 \%$ rate:

- has no interest in any other Hungarian company,

- none from owners or shareholders is a Hungarian resident,

\footnotetext{
${ }^{2}$ Lenain, Bartoszuk (2000)
} 
- can be involved in business operation only with non-residents according to VAT rules,

- most management members are Hungarian residents,

- is audited by a Hungarian company,

- and operational expenses are financed from a bank account in Hungary.

This preferential regime is available for companies registered by 2000 till the end of 2005 and for companies registered later and satisfying the conditions only till the end of 2003.

\subsection{Slovakia}

After separation from Czechoslovakia, the inflow of FDI was negligible due to clear preference of domestic investors by the government. Not earlier then in 1998 the government introduced a tax credit, which allowed exemption from income tax for particular activities.

Since 2000 a new Income Tax Act extended the applicability of the tax credit. It is a conditional exemption, since the company has to prove that money saved from the unpaid tax were used for purchase of assets for the exempted business activities. The exemption is applied to companies with at least $75 \%$ of foreign participation, if a monetary contribution to the equity is at least 5000000 EUR (half of the amount in regions with an above $15 \%$ unemployment) and the company has at least $60 \%$ of turnover from manufacturing of exported goods or goods not produced in Slovakia so far. For software development and tourist business companies the threshold is only 1500000 EUR. The exemption is granted for five years, in case of additional contribution to the equity, the company can opt for a $50 \%$ reduction in additional 5 years.

\subsection{Czech Republic}

The Czech Republic was the last country in the region, which introduced investment incentives. The government used to believe for a long time, that a stable currency, inexpensive and educated labour force and good infrastructure are good enough to give the Czech Republic a competitive advantage ${ }^{3}$. However, after it had lost several big investment projects, the parliament adopted on 1.5. 2000 a new Investment Incentives Act ${ }^{4}$.

According to the Act nowadays the investor can receive four kinds of investment incentives:

1. reduction of income tax,

2. grants to municipalities for infrastructure at the construction site (up to $60 \%$ of costs),

3. grants for newly created jobs (80-200 000 CZK per job, e.g. $2000-5000$ USD),

4. grants for retraining of employees (25-35\% of costs).

The investor can get the incentives, if he invests at least $350000000 \mathrm{CZK}$ (10 mil. USD, half of the amount in regions with higher unemployment) in stipulated activities (manufacturing, aircraft industry, IT, telecommunications, pharmaceutical industry). The amount of the incentive depends on the regional unemployment. Grants for newly created jobs and retraining can be obtained only if the regional unemployment is by $25 \%$ higher then the average in the country.

Reduction of the income tax does not depend on the unemployment rate. Greenfield investments enjoy a $100 \%$ reduction of the current $31 \%$ corporation tax rate for ten years. Investment projects for extension of current capacities or modernisation, are eligible for a partial reduction of the corporation tax for five years. The tax liability is based on the tax liability assessed in the last two years (higher one) so that the tax paid in the next five years is at least that amount. The taxpayer must be the first owner of the purchased assets, must not be wound up, merge and go bankrupt. Moreover the taxpayer has to minimise its tax base by all allowed means offered in the Income tax Act.

Additionally the investor can import machinery and production equipment without import duties and VAT if their value exceeds $10000000 \mathrm{CZK}$, are not older then one year and in four subsequent years will be only in the ownership of the investor. Recently the government approved first two pilot projects for strategic services (shared service centre and expert centre). However such incentives are so far approved only by a government decision.

\subsection{Investment incentives and EU rules}

The ultimate amount of the investment incentive is however determined by the Act on the Public Support ${ }^{5}$, which respects the rules ${ }^{6}$ of the European Union for the state aid for a national regional support. The document sets the limits for available amount of investment incentives depending on the type of region, where the investment takes place.

The regions are divided into three categories according to GDP per capita. Czech republic is in the third category, where GDP per capita is lower then $75 \%$ of EU average. The legal amount of public support must not

\footnotetext{
${ }^{3}$ Roach D., 1995, Czech Republic: Fine Tuning of Tax Laws, European Taxation, vol.14

${ }^{4} \mathrm{Nr} .72 / 2000$ coll.

${ }^{5}$ Act on Public support Nr. 59/2000 coll.

${ }^{6}$ 98/C 74/06
} 
exceed $50 \%$ of capital costs of the investment project (purchase of land, buildings, machinery and intangible assets). Grants for retraining of labour force are not considered within this limit.

From 2002 the legal limit of the public support will be determined according to GDP per capita in each region (NITS II). It means that for some regions, for instance Prague, the capital, the limit will be reduced.

\section{Inflow of foreign direct investments in CEE countries}

Fundamental question in evaluation of efficiency of investment incentives is, whether they really attract more foreign investments in the host country. We looked into data published by IMF and OECD (see table 1). Unfortunately the figures include all foreign investments, not only the investments, which qualified for investment incentives but also privatisation and sales of established companies to strategic partners. The biggest privatisation cases were excluded from the table, but still, the values are a bit ambiguous.

We cannot entirely determine, whether the countries are stealing investments each other or whether they attracted new investments, which became profitable without the corporation tax. However from the growing trend (column Total CEE) we can argue, that the latter case is more probable. Szanyi (1999) talks about resource-oriented (pushed by low production costs) investment as opposed to market-oriented investment aimed mostly at purchase of market position.

However we can see that in the years, when there were no investment incentives in the Czech Republic, the inflow of FDI lacked behind Poland and Hungary. As well as in Poland and Hungary, the inflow of FDI accelerated after special economic zones were created or preferential regimes introduced.

Table 1: Inflow of foreign direct investments into CEE countries 1989-1998 mil. USD

\begin{tabular}{|l|l|l|l|l|l|l|l|}
\hline & Austria & Germany & $\begin{array}{l}\text { Czech } \\
\text { Republic }\end{array}$ & Hungary & Poland & Slovakia & Total CEE \\
\hline 1989 & 587 & 7152 & n.a. & 187 & 11 & 10 & 208 \\
\hline 1990 & 653 & 2532 & n.a. & 311 & 89 & 24 & 424 \\
\hline 1991 & 360 & 4108 & n.a. & 1462 & 291 & 82 & 1835 \\
\hline 1992 & 1442 & 2642 & 983 & 1479 & 678 & 100 & 3240 \\
\hline 1993 & 1129 & 1946 & 654 & 2350 & 1715 & 199 & 4918 \\
\hline 1994 & 2117 & 1936 & 878 & 1144 & 1875 & 270 & 4167 \\
\hline 1995 & 1901 & 11986 & 1118 & 2819 & 3659 & 236 & 7831 \\
\hline 1996 & 4485 & 6429 & 1435 & 2274 & 4498 & 351 & 8558 \\
\hline 1997 & 2624 & 11663 & 1286 & 2167 & 4908 & 174 & 8535 \\
\hline 1998 & 6034 & 20145 & 2737 & 2037 & 5761 & 562 & 11098 \\
\hline 1999 & 2979 & 52230 & 5091 & 1650 & 5589 & 354 & 12684 \\
\hline $89-99$ & 24311 & 122769 & 14182 & 17880 & 29074 & 2362 & 63498 \\
\hline Per cap. & 3001 & 1477 & 1377 & 1770 & 751 & 437 & \\
\hline
\end{tabular}

Source: IMF Statistics, EBRD

Notes:

1995 - excluded sale of MATAV (Hungary 1,7 mld. USD) and Telecom (Czech Republic 1,45 mld. USD)

1998 - excluded sale of Bank Handlowy (Poland 604 mil. USD)

1999 - estimates EBRD

1999 - excluded sale of Pekao (1,1 mld. USD), Bank Zachodni (581 mil. USD) in Poland

In italics are years when large-scale investment incentives were provided.

When analysing the tax competition it is useful to pay attention to tax revenues from the corporation tax, since that tax should be affected most. It is not surprising, that the lowest revenue is in Hungary, however in comparison with the Czech Republic it has a stable and thanks to an inflation a growing trend. In the Czech Republic the trend is decreasing.

Nevertheless we have to be cautious in interpretation, since the corporation tax is sensitive to the performance of the economy. Growth of GDP in Poland and Hungary in contrast to recession in the Czech Republic is probably the most important factor of the difference in trends. Unfortunately we do not have more detailed data about tax revenues from foreign owned companies in the analysed economies.

Our conclusion is that the investment incentives in Hungary did not affect the tax revenues in Poland in a negative way, but might have decreased its own tax revenue. We can see it from a lowest value of the TGP coefficient (see table 2). However the Czech Republic might have been affected, even though we cannot support this conclusion without analysis of the influence of the business cycle on tax revenues, but is not probably the case as the value of the TGP coefficient indicates. Also the reliability of the data from the beginning of the 
transformation process is lower.

Table 2: Revenues from corporation tax in CEE countries in mil. USD.

\begin{tabular}{|l|l|l|l|l|l|}
\hline & Austria & Germany & $\begin{array}{l}\text { Czech } \\
\text { Republic }\end{array}$ & Hungary & Poland \\
\hline 1993 & 2670 & 25705 & 2411 & 606 & 3111 \\
\hline 1994 & 2696 & 24371 & 2367 & 755 & 2967 \\
\hline 1995 & 3594 & 26157 & 2482 & 746 & 3788 \\
\hline 1996 & 4589 & 32768 & 2318 & 770 & 3949 \\
\hline $\begin{array}{l}\text { TR/GDP/ } \\
\text { pop. }\end{array}$ & 0,02567 & 0,01807 & 0,01800 & 0,00713 & 0,01308 \\
\hline
\end{tabular}

Source: OECD Revenue Statistics

Note: TR/GDP/pop. (TGP coefficient) - ratio between tax revenues and GDP and population

As obvious from the table 3, the trends of reduction of corporation tax are not limited only to investment incentives or tax holidays. Tax rates fall in most countries. It is mostly a reaction to the lower competitivness of domestic industry and preference of domestic industry to imports, since customs duties were within CEFTA already repealed and most CEE economies are export oriented.

Table 3: Corporation tax rates in 1993, 2000 and target rates.

\begin{tabular}{|l|l|l|l|}
\hline Tax rates & 1993 & 2000 & Target rates \\
\hline Czech Republic & 45 & 31 & 25 \\
\hline Poland & 40 & 32 & 22 \\
\hline Slovakia & 45 & 29 & 25 \\
\hline Hungary & 40 & 18 & 18 \\
\hline Austria & 30 & 34 & 34 \\
\hline Germany & 45 & 40 & 25 \\
\hline
\end{tabular}

Source: MF Germany, Lenain, Bartoszuk (2000)

Tabule 4: Minimum investments, which are eligible for $100 \%$ reduction of the corporation tax.

\begin{tabular}{|l|l|l|}
\hline Country & Legal limit & EUR Equivalent \\
\hline Poland & 2000000 EUR & 2000000 \\
\hline Slovakia & 5000000 EUR & 5000000 \\
\hline Hungary & 1000000000 HUF & 4000000 \\
\hline Czech Republic & 350000000 CZK & 10000000 \\
\hline
\end{tabular}

Source: Easson (2000), Act on Investment Incentives, Income Tax Act

\subsection{Correlation analysis}

For evaluation of efficiency of investment incentives for the state budget we can use several methods:

1. Quantification of costs and benefits for the budget - unfortunately we do not have enough data for that method. They can be gathered only by a government institution, which controls drafting of tax credits, otherwise the administration secrecy would be breached. Therefore, we could not use that method.

2. Estimates of the trend function of tax revenue, since the investment incentives should cause a fall in the revenues from the corporation tax. We do not have sufficient data for this method, since OECD publishes the revenue statistics with a three-year delay. So we do not have those statistic at all for the period, when such incentives have been effective in the Czech Republic. From a simple comparison of the revenues from the corporation tax is obvious that as opposed to Poland and Hungary the revenue in the Czech Republic was stagnating or even decreasing. The reason is probably neither the cut of the rate, which was significant (from $45 \%$ to $39 \%$ ), but which occurred also in other countries nor the coming economic recession which peaked in 1998 and 1999. Our opinion is that it can indicate a tax competition, because the Czech Republic failed to attract profitable firms and technologies to replace falling tax revenues from declining state companies.

3. A third method is based on statistical tests and a correlation analysis of the FDI series - We performed two kinds of analysis, the first one is based on the conditional equality of means of two time series, before and after the introduction of investment incentives in Poland and the Czech Republic. The null hypothesis assumes that after separation of the trend function the means in both time series are equal. It 
is a suitable test for short time series, since it is based on the assumption of the random choice of the values. Even though our data fully do not meet this condition, this method most reliable results. Second we tried also the correlation analysis of inflow of FDI to Poland and Czech Republic against Hungary, where a negative correlation means a switch of FDI flow from one country to another.

We have tested data series for 1989-99 in Poland and 1993-99 in the Czech Republic. The hypothesis on conditional equality of means for two periods 1993-97 and 1998-99 was rejected ( $p$ - 0,00296). Thus the incentives had an impact on the inflow of FDI to the Czech Republic. Similar results gives the test on difference between the amount of FDI before and after the introduction of the investment incentives in Poland in 1995 ( $p$ 0,00002).

As we stressed earlier our research question is, whether the flow of FDI only switched within the region or a new wave of investments from other part of the world was attracted. We have found a strong negative correlation between flow of FDI to Hungary and the Czech Republic - coefficient of correlation - 0,8364 ( $p$ $0,0775)$ and for Poland and Hungary the coefficient of correlation for flow of FDI was even higher $-0,9109(p$ $0,0315)^{7}$

Tabule 5.5: Coefficients of correlation for inflow of foreign direct investments.

\begin{tabular}{|l|l|}
\hline ČR - Hungary & $-\mathbf{0 , 8 3 6 4}$ \\
\hline Poland - Hungary & $\mathbf{- 0 , 9 1 0 9}$ \\
\hline ČR - Poland & 0,7205 \\
\hline
\end{tabular}

Source: Calculated wit software - see annex, time series 1995-99.

Note: Bold values are significant on $90 \%$ confidence level.

We can conclude, that introduction of tax incentives in Poland has probably caused stagnation of inflow of FDI to Hungary. Later on again the introduction of investment incentives in the Czech Republic decreased flow of foreign investments into Hungary but not to Poland. It verifies conclusions of the theory of the tax competition, that such kind of intergovernmental competition is effective especially in case of symmetric countries. In case of asymmetry in the size of the country the larger country has a competitive advantage of a large market and tax factors play a minor role.

\section{Conclusions}

We have to stress that the tax competition in the CEE countries had no influence on tax revenues and did not endanger state budgets. On the other hand the inflow of FDI contributed to the growth of GDP and successful restructuring of the economy as Khac, Sedmihradsky (2001) showed. Another important conclusion is that the tax measures described in the previous text does not meet characteristics of the harmful tax competition set in OECD (1998). The investment incentives are open to all taxpayers not only to non-residents and with transparent criteria. In the Czech Republic they can be granted only for manufacturing projects, so a real economic activity in the country is required. Moreover the amount of the incentives (and the reduction of the income tax) depends on the invested amount, which makes the scheme transparent and accountable.

Every project is under the supervision of the local tax administration and the Czech agency for foreign investments - Czechinvest. We may conclude that abuse of the local schemes of investment incentives for a tax avoidance of EU-residents is almost impossible. There is only a problem of the Hungarian offshore company, however by 2005 this problem should be eliminated as required by OECD (1998).

The investment incentives are highly effective in attracting foreign investments. However it is necessary to note, that to give the investor tax holidays is nowadays not enough. The country has to have a welldeveloped system, which will help the investor to realise his project within the investment scheme fast and without additional administrative costs. It is not important if a government agency or a private consultation company will guide the investor.

On the other hand we can understand the fear of the current EU-members about the outflow of hightech investments from their territory. So far there is not any evidence from that outflow. First some member states are even more generous in provision of investment incentives then the candidate countries. The investment support in sensitive industries is already under a careful supervision of the European Commission ${ }^{8}$, which has an ultimate word, even though that there is no representation of candidate countries in this institution. Second the figures (see for instance table 1) do not show any decrease of an investment inflow into EU-countries, since the

\footnotetext{
${ }^{7}$ For comparison - the coefficient of correlation for inflow of FDI between Poland and CR is 0,7205 $(p-0,1697)$.

${ }^{8}$ For instance a Czech car manufacturer Skoda applied in 1998 for an investment support 26\% of the capital costs. However as agreed with the European Commission, the investment support for this company can be only $4,6 \%$ of the capital costs - see Ekonom 45/2001 p. 46
} 
CEE countries more compete for the investments with each other and with Asian countries. Third the investments incentives can target much more precisely industries with higher added value and more environmental friendly production. Such investments will increase the competitive position not only of one country, but also of the whole Union. Finally the investment incentives are mostly designed to solve the regional structural problems, which is fully compatible with the cohesion targets of the European Union.

We can therefore sum up, that the tax incentives for an investment project do not constitute a danger for the single market if:

- the support is based on a legal framework and limited from the beginning of the project,

- $\quad$ it is designed to encourage investments in manufacturing industry,

- it supports investments in less developed regions (with low per capita GDP) or regions with high structural unemployment,

- they are open to both residents and non-residents and there is no limitation of ownership,

- the decision about the provision of the incentive and its amount is transparent and involves both tax and competition authorities,

In such a case the investment incentives only cover the risk associated with an investment environment and allow a full taxation of the economic profit, which is in line with the theory of optimal taxation. We should not put an additional burden on the desired economic activity, on the other it is not a reason for a complete elimination of the corporation tax.

An important question for a further research is, how to balance a provided investment scheme, that it offsets the disadvantages, which the investor has from investing in a less developed region or a country so the investment incentives are a fair tool but still simple and easy to administer.

\section{References}

1. Black Dan A., Hoyt William H., 1989, Bidding for Firms, American Economic Review 79

2. Boss A., Gern K.-J., Meier C.-P., Scheide J., Schlie M., 1999, For a Stable Moentary Policy and Tax Competition in Euroland, Institut für Weltwirtschaft Kiel WP 338

3. Easson Alex, 1998, Duty-Free Zones and Special Economic Zones in Central and Eastern Europe and the Former Soviet Union, Tax Notes International, February 9, 1998, p. 445

4. European Commission, 1997, Communication towards Tax Competition in the European Union: Code of Conduct for Business Taxation, COM(97) 495

5. Khac N. L., Sedmihradsky M., Svarcova I., Trytko D., 2001, Tax and Social Security Systems for Economic Growth, paper delivered at the $57^{\text {th }}$ Congress of the International Institute of Public Finance

6. Lenain Patrick, Bartoszuk Leszek, 2000, The Polish tax Reform, OECD, WP 234

7. OECD, 1998, Harmful Tax Competition: An Emerging Global Issue

8. Szanyi Miklós, 1999, The role of FDI in restructuring and modernization: an overview of literature, in: Integration through FDI: Making CE industries more competitive, WIW, Edward Elgar

9. Tanzi Vito, Zee H. Howell, 2000, Tax Policy for Emerging Markets: Developing Countries, International Monetary Fund WP/00/35

10. Tiebout, 1956, A pure theory of local government expenditure, Journal of Political Economy

11. Wilson John D., 1999, Theories of Tax Competition, National Tax Journal, June 1999

12. www.czechinvest.cz. Czech Agency for Foreign Investments 